\title{
Magnetic Susceptibility of Soils from Eastern Botswana: A Reconnaissance Survey and Potential Applications
}

\author{
Rubeni T. Ranganai ${ }^{1}$, Moikwathai Moidaki ${ }^{1} \&$ James G. King $^{1}$ \\ ${ }^{1}$ Department of Physics, University of Botswana, Gaborone, Botswana \\ Correspondence: Department of Physics, University of Botswana, P. Bag UB0704, Gaborone, Botswana. Tel: \\ 267-355-2465. E-mail: ranganai@mopipi.ub.bw
}

Received: October 14, 2015

Accepted: November 4, $2015 \quad$ Online Published: November 26, 2015

doi:10.5539/jgg.v7n4p45

URL: http://dx.doi.org/10.5539/jgg.v7n4p45

The research is financed by the University of Botswana.

\begin{abstract}
Soil magnetic properties measurements are relatively fast and inexpensive but have been proved to be sufficient for preliminary investigations in diverse socio-developmental issues. This paper presents results of a reconnaissance study of soil colour and magnetic susceptibility $(\chi)$ in eastern Botswana, where $\sim 80 \%$ of the population resides. The work is a first step to creating a database of rock and soil magnetic properties and to document spatial variations in magnetic properties in the country. These measurements are important as constraints for interpretation of available aeromagnetic data and can also be exploited for environmental soil research (pollution) and land-use planning (agriculture). The soils sampled include derivatives of varying types and provenance such as Archean gneissic granitoids, metamorphosed rocks (granulites), volcano-sedimentary assemblages, Karoo basalts, and alluvial sediments. A soil colour chart was used since soil colours and magnetic properties are diagnostic of its parent rock sources and weathering profiles. Soil magnetic susceptibilities were measured at both low frequency $(0.46 \mathrm{MHz}, \chi \mathrm{lf})$ and high frequency $(4.6 \mathrm{MHz}, \chi \mathrm{hf})$, thus allowing calculation of frequency-dependent susceptibility $(\chi \mathrm{fd}, \chi \mathrm{fd} \%)$ for detecting ultra-fine ferromagnetic minerals.

It was found that soils with Hues ranging from $7.5 \mathrm{YR}$ to $10 \mathrm{YR}$ have appreciable amount of magnetic materials and soils with Hues of $2.5 \mathrm{YR}$ are generally nonmagnetic. The results of soil magnetic susceptibility profiles show spatial variation closely related to the variation in basement rocks, which provides excellent evidence that the magnetic susceptibility variation reflects basement rocks or bedrock composition (soil parent material). In relation to the Botswana physiographic units, soils from the hardveld (Precambrian) show the highest susceptibilities, followed by those from the sandveld, with the lowest values being from the alluvial. The frequency dependent magnetic susceptibilities indicate the presence of ultra-fine super-paramagnetic minerals such as magnetite/maghemite. It is suggested that a systematic and continuous programme of rock and soil magnetic measurements would benefit various socio-economic and development priority sectors of Botswana. This also applies to many developing countries in Africa where soil physics and measurement of soil susceptibility in particular, is generally still at an embryonic stage.
\end{abstract}

Keywords: magnetic susceptibility, soil colour, magnetic mineralogy, ferromagnetic minerals, frequency dependent susceptibility, Botswana

\section{Introduction}

Economies in many southern African countries, including Botswana, largely rely on mining and agriculture, and several programmes have been instituted to enhance and promote these sectors. These include several airborne magnetic surveys to improve geological and structural mapping for both mineral and groundwater exploration; airborne radiometric surveys; remote sensing interpretations, review of industrial minerals, as well as soil and aggregate studies for agricultural and industrial purposes (e.g., Moidaki, 2001; van Straaten, 2002; Ranganai et al., 2006). Aeromagnetic surveys have proved to be the most cost-effective tool in mapping complex geology and sporadic outcrops (e.g., Gunn et al., 1997), as the data are relatively unaffected by the presence of surficial material such as weathering or overburden. This is the case for Botswana where exposure of pre-Tertiary formations is restricted to about $25 \%$ of the country (e.g. Carney et al., 1994; Key \& Ayres, 2000), mainly in the 
eastern part (Figure 1). However, proper interpretation of the growing geophysical data set requires petrophysical data (e.g., Clark, 1997), which currently does not exist for Botswana. Therefore there is a need for a database of rock and soil magnetic properties. Fortunately, the concentration of magnetic minerals (mostly magnetite) in rocks and soils can be expressed, with some simplification, by magnetic susceptibility, thus reducing most investigations to the simple measurement of only one parameter (Thompson \& Oldfield, 1986; Evans \& Heller, 2003). However, this would not give information on the grain sizes of the minerals.

In Botswana, most soil related research and developmental effort has mainly been oriented to (focused on) agriculture and, to some extent urban planning, in combination with a land systems map (e.g., De Wit \& Nachtergaele, 1990; Pule-Meulenberg \& Batisani, 2003). No systematic investigations of the spatial distribution of topsoil magnetic properties have been performed in the country. Magnetic properties of soils are influenced significantly by the bedrock lithology and soil-forming processes; and can therefore assist in broad geological mapping and interpretation (e.g., Allan, 1986; Puranen, 1989; Fontes et al., 2000; Ishihara et al., 2002; Retallack et al., 2003; Fialova et al., 2006; Lu et al. 2008). Although the variable contributions of lithogenic or pedogenic minerals to bulk magnetic susceptibility of soils cannot be easily quantified, it is possible to classify soils with respect to the property. Several authors have shown that magnetic susceptibility can be used successfully to describe soil-profile development (e.g., Maher, 1986; Dearing, 1999) and palaeo-climatic changes (Herries \& Latham, 2003; Maher et al., 2003; Lyons et al., 2010), to identify lithology of soil parent materials (Fontes et al., 2000; Fialova et al., 2006), to aid in soil taxonomy (Yoshida \& Kallali, 2003), and to assess heavy metal pollution (Petrovsky \& Ellwood, 1999; Hanesch \& Scholger, 2002; Jordanova et al., 2008) as well as unexploded ordinance (UXO) (Hannam and Dearing, 2008; Preetz et al., 2009).

In this study, we present the results of a relatively extensive but quick and inexpensive reconnaissance study of some soil magnetic properties in eastern Botswana (Figure 1), where there is relatively good rock exposure and $\sim 80 \%$ of the population resides. The primary objectives of the study are: 1) to study the magnetic susceptibilities $(\chi)$ of the different soil samples and establish a database of typical susceptibility values for the different soil types; 2) to understand the link between magnetic properties and soil type and parent material, thus complementing established soil analytical techniques; and 3) to build up a national database of soil static and dynamic properties, useful for academic, developmental use and environmental research. A secondary objective of this study is to investigate whether the $\chi$ values have frequency dependence and to detect the ultra-fine particles by employing both low frequency and high frequency susceptibility measurements. Understanding magnetic properties through direct measurement of magnetic susceptibility in the field, supported by laboratory studies of magnetic petrophysics and petrology, provides the basis for more effective use of existing aeromagnetic data as a geological mapping and mineral exploration tool as well as for environmental applications (e.g., Grant, 1985; Reeves, 1989; Hunt et al., 1995; Clark, 1997; Ishihara et al., 2002; Alva-Valdivia et al., 2003). The results can also contribute to the improvement of (general) models for prediction of magnetic susceptibilities of tropical soils and/or arid to semi-arid soils important for electromagnetic prospecting (cf Singer et al., 1996; Van Dam et al., 2005, 2006; Preetz et al., 2009).

\section{Regional Geological and Geomorphologic Setting}

Botswana is a relatively flat, arid to semi-arid, and land locked country of $\sim 583000$ square kilometres with a population of about 2.0 million. About $80 \%$ of the population resides in the southern and eastern parts of the country (encompassing the study area, Figure 1), where favourable conditions permit widespread cattle ranching and limited subsistence crop farming (e.g., DLFRS, 1985; De Wit \& Nachtergaele, 1990). These areas are underlain by continental crust constituting the Archaean Zimbabwe and Kaapvaal Cratons, and the adjoining (intracratonic) Neoarchaean Limpopo Belt (Figure 1) (Carney et al., 1994; Key \& Ayres, 2000) comprising gneissic granitoids with associated metasedimentary and metavolcanic rocks. The geology of the country is largely obscured (about 75\%) by Cretaceous to Recent Kalahari Beds, consisting mainly of aeolian sands (Figure 1) called Kalahari sands, which range in depth from less than $20 \mathrm{~m}$ in the east to more than $200 \mathrm{~m}$ in the west (Carney et al., 1994; McEwen, 1979). The Kaapvaal and the Zimbabwe Cratons were generated during two major tectonic cycles which involved the formation of greenstone belts (or schist belts) and granitoids. The low-grade greenstone belts host several mineral deposits including $\mathrm{Au}, \mathrm{Cu}, \mathrm{Ni}$ and several geological mapping programmes have been undertaken in these areas. In Botswana, the Limpopo Belt consists of a variety of high grade metamorphosed rocks, mainly granitoid gneiss (Carney et al, 1994; Key \& Ayres, 2000) and also contains numerous mineral occurrences including the Selebi-Phikwe copper-nickel deposit hosted in ultramafics (Key, 1976). The western margin of these Archaean rocks is covered beneath a cover of Karoo rocks, including thick basaltic lavas, and Kalahari sediments, mainly of continental-fluvial origin. Most diamondiferous kimberlites of the country occur on this margin, including the Orapa and Letlhakane fields (Figure 1). Vast amounts of coal 
resources exist in the Karoo Supergroup, giving Botswana the second largest coal reserves in Africa, after South Africa (Capital Resources, 2013).

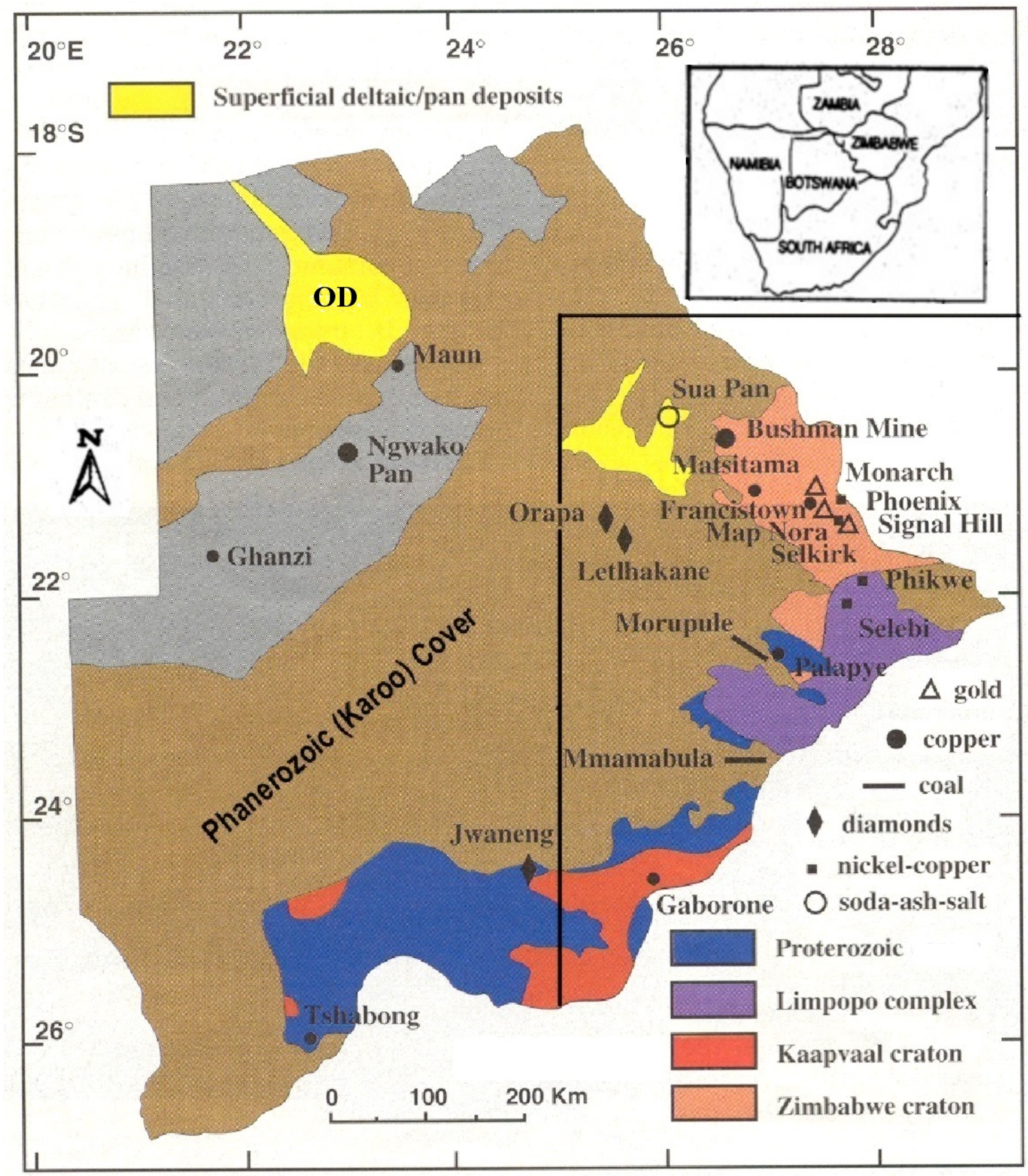

Figure 1. Outline geology of Botswana, showing the study area and main mineral deposits in the eastern parts of the country (modified after Williams et al., 1999). OD = Okavango Delta. Inset shows the location of Botswana in southern Africa

The country's soils were formed through the interaction of four main factors: the parent rock from which the soil was derived, the relief of the land as it affects the drainage characteristics along hillsides and valleys, past climatic cycles that have facilitated or retarded weathering of parent materials, and time (Denbow \& Thebe, 2006). The principal physiographic units of Botswana soils reflect the interactions of these factors. In general, the country is divided into four physiographic units namely, sandveld, hardveld, lacustrine and alluvial, that are related to the Kalahari sands, Precambrian rocks, (old, dried up) lake deposits, and alluvial/aeolian deposits, respectively (De Wit \& Nachtergaele, 1990). The sandveld covers almost two-thirds of the country and receives 
the least amount of rainfall while the hardveld covers most of the eastern region where rainfall is higher. Thus, the Archaean and Palaeoproterozoic rocks occupying parts of eastern Botswana (the study area) constitute the hardveld; characterised by soils which have been weathered from the acid igneous and metamorphic rocks in the area, as well as soils from alluvial sediments. Most of the soils here have a ustic moisture regime (between aridic and humid), with the rest of the country being aridic (De Wit \& Nachtergaele, 1990). This includes silty sands and sandy clays with a predominant light brown to brown colour, with some grey sandy soils in the western area. Subsoil materials consist mainly of weathered and decomposed granites with laterite, calcrete and quartz gravel layers influencing the colouring of the topsoil layer. In the study area, lacustrine soils (evaporates) are restricted to the northwest corner of the area in the Makgadikgadi basin where reserves of soda ash and salt are extracted from Sua Pan (Figure 1).

\section{Materials and Methods}

\subsection{Sample Collection and Preparation}

Magnetic properties of matter are largely controlled by the amount of iron present (Hunt et al., 1995). Iron occurs in one form or another in many soils. Iron-containing minerals can be found in igneous rock such as basalt, gabbro, and granite, but also in metamorphic and sedimentary rocks (Puranen, 1989; Cornell \& Schwertmann, 2003). Soil samples were collected in the eastern side of Botswana along the major road network between latitude $19.5^{\circ} \mathrm{S}$ and $25^{\circ} \mathrm{S}$ and longitude $25.5^{\circ} \mathrm{E}$ and $29.5^{\circ} \mathrm{E}$ (Figure 2). The soils sampled formed in different parent materials: igneous, metamorphic and sedimentary rocks; granites/gneisses, basalt, greenstones, alluvial deposits, calcareous rocks and sediments, and others (Figure 1). Samples were collected at $10 \mathrm{~km}, 5 \mathrm{~km}$ and/or $1 \mathrm{~km}$ intervals using the vehicle odometer and about $100 \mathrm{~m}$ from the main road to minimize anthropogenic effects and were kept in diamagnetic plastic containers. In particular, this distance helped to avoid transported material and contamination from metal debris left during road construction and from vehicle exhaust fumes (cf Hoffmann et al., 1999; King \& Ranganai, 2000; Kim et al., 2007). Plastic shovels were used to avoid 'mineral' contamination and samples were obtained at a depth of 5-30 cm (topsoil), while avoiding compost (organic) material (cf Shi \& Ciopaa, 2006). Field work was carried out during the dry season and thus reducing moisture problems (cf Schibler et al., 2002; Maier et al., 2006). Sample containers were labeled with a 'permanent' marker and additional paper labels placed inside containers in case labels on the surface were erased during transportation. The location of most samples was recorded by a Garmin GPS receiver with a precision of $\pm 10 \mathrm{~m}$ enabling future re-occupation if and when necessary (Figure 2).

Soil samples used for this study were obtained along roads leading to various settlements (Figure 2) on different trips and results are presented accordingly. The different segments of the routes make the profiles highlighted in Figure 2 for general discussion of geotectonic provinces, with profiles P1 to P3 approximately perpendicular to the general geological strike of formation as much as possible. Trip 1 (equal to Profile P1) involves soil samples collected from Ramatlabama to Ramokgwebana along the main tarred road across the country, from the Kaapvaal craton (basement complex with Proterozoic cover) in the south through the Limpopo belt central zone (highly deformed granulite gneisses) to the Zimbabwe craton in the north (basement complex plus greenstone belts).

Trip 2 samples were obtained from Gaborone - Molepolole - Sojwe/Lephephe - Shoshong - Serowe Mmashoro - Mokubilo - Francistown, and large sections are covered by Karoo Supergroup mainly comprising arkose, carbonaceous mudstone, shale; and basalt with minor sedimentary lenses ( 180 Ma). Trip 3 data was obtained along Palapye - Serowe - Paje - Dimaje - Sebina - Tutume - Maitengwe - Sepako - Nata, and then Francistown; areas underlain by the basalts from Karoo Supergroup, aeolian sandstone and locally calcareous with subordinate mudstone. Trips 2 and 3 approximately constitute Profile P3 which mostly traverses the sandveld in the extreme west towards the Kalahari. Data for Trip 4 was acquired along Serule - Selibe Phikwe Sefophe - Bobonong, and then from Bobonong - Sefophe - Palapye (blue in Figure 2). These areas are within the Limpopo Belt central zone of highly deformed granulite gneisses and Karoo basalts (Key, 1976). Data for Trip 5 was obtained from Mochudi - Ramonaka - Martin's Drift - Zanzibar - Point Drift - Bobonong -Selibe Phikwe - Mmadinare - Tonota. These areas are underlain by Kaapvaal craton (basement complex with Proterozoic cover) in the south through Limpopo belt central zone (highly deformed granulite gneisses) to the Zimbabwe craton in the north (basement complex plus greenstone belts). Trip 5 approximately constitutes Profile $\mathrm{P} 2$ over the hardveld. The total number of samples collected is 372 (Figure 3). 


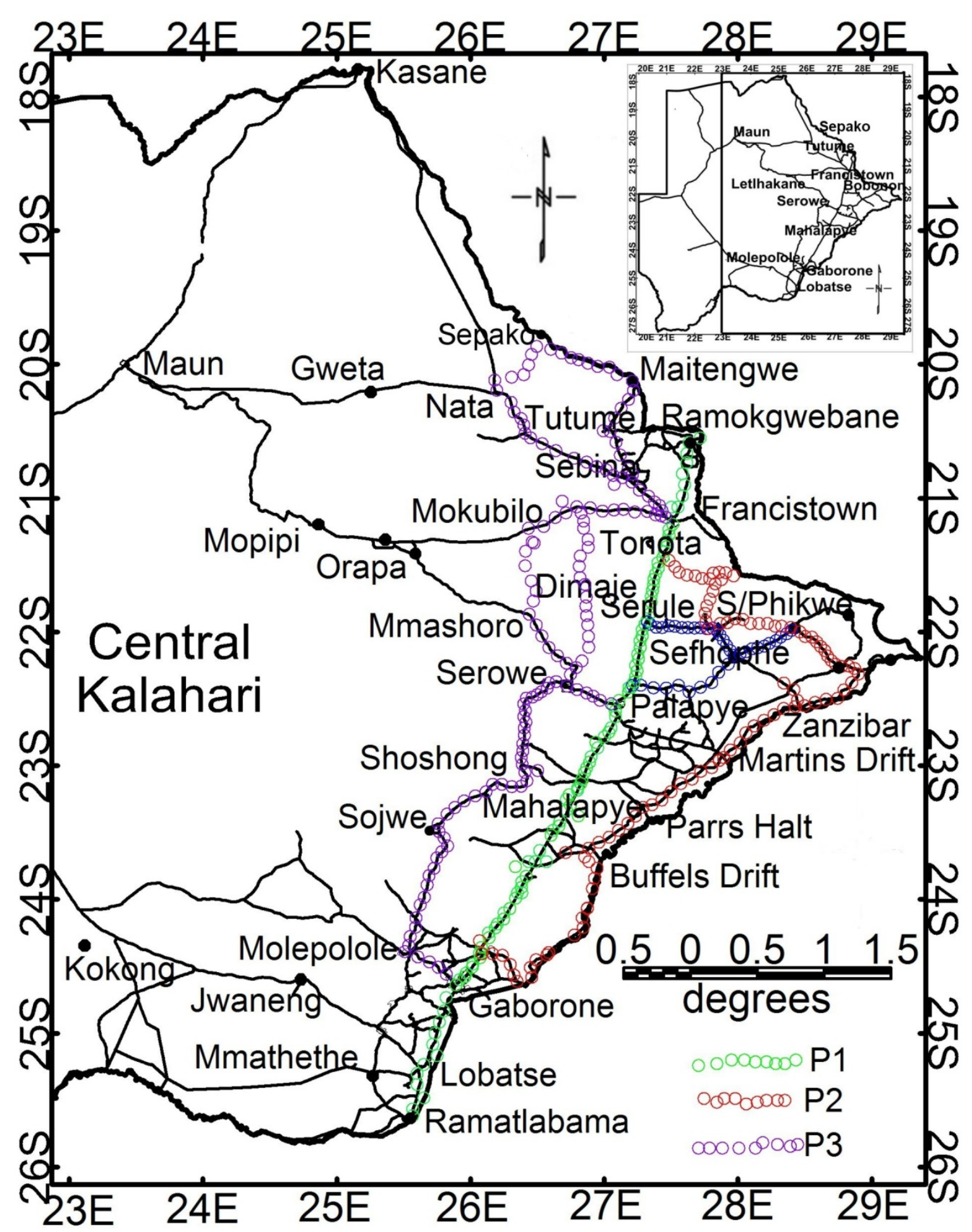

Figure 2. Sampling routes in eastern Botswana showing most settlements and sample points. The three main profiles discussed in text are shown (P1 and P2 in the hardveld and P3 in the sandveld). Inset shows the location of the study area (this figure) within Botswana

In the laboratory the samples were air-dried for a minimum of 48 hours at room temperature $\left(<30^{\circ} \mathrm{C}\right)$, so as not to cause any chemical reactions (cf Maier et al., 2006). The portable Bartington MS2B (Dearing, 1999) single sample dual frequency sensor used for measurement accepts $10 \mathrm{~cm}^{3}$ samples in plastic pots while the MS2W uses $2.5 \mathrm{ml}$ cylindrical samples. An electronic balance with $0.1 \mathrm{mg}$ accuracy was used to measure the $10 \mathrm{~cm}^{3}$ 
pots while empty and after filling them with soil. Where necessary, soil material was crushed to sandy grain sizes in order to fill the sample holder. After measuring the magnetic susceptibilities, the bulk density ( $\rho$ ) was calculated by dividing the mass of each sample by its volume (i.e. $10 \mathrm{~cm}^{3}$ ). Mass specific susceptibility was then calculated (section 3.3).

\subsection{Soil Colour Determination}

Soil colour is the most obvious feature of the soil and is easily seen by the naked eye, and an experienced observer can often relate soil colour to specific chemical, physical and biological properties of the soil in an area (e.g., Buol et al., 1973; Townsend, 1973). In some instances, relic colours, that is those inherited from the initial materials, persist in the soil (Townsend, 1973). Many tropical soils have deeply weathered profiles whose red and yellow colours result from an accumulation of iron and aluminum oxides. Iron oxide minerals can be both pedogenic (i.e., a product of soil formation) and lithogenic (i.e., unweathered minerals from the parent material) in origin (Cornell \& Schwertmann, 2003; van Dam et al., 2006; Lu et al., 2008). Magnetic susceptibility gives an approximate indicator of concentration of the ferrimagnetic minerals in the soil, thus a close relationship between iron content, soil colour and magnetic susceptibility is observed/expected (e.g., Nagano \& Nakashima, 1989; Hanesch \& Scholger, 2005). For example, Allan (1986) found a close relation between soil colour and magnetization for samples from mafic rocks but not for those from other rocks. Magnetic and non-magnetic minerals in soils can be identified by the colour of the soil. Specific types of iron oxides, iron-titanium oxides and iron sulphides are the predominant causes of magnetic soil characteristics (Cornell \& Schwertmann, 2003; Hendrickx et al., 2005). In abundance, iron (Fe) is the fourth element in the earth's crust (Hunt et al., 1995).

The soil colour for each sample was determined using the Munsell soil colour chart that conventionally requires visual matching of a sample with standard colour chips (Munsell Colour, 1994). The system employs three perceptually uniform scales (hue, value (lightness), chroma (colour purity)) defined in terms of daylight reflectance. The Munsell colour notations are expressed as a number and one or two capital letters representing hue (e.g., 10 YR, 5 Y, etc.) while value and chroma are each represented by a number (e.g. 5/6, 7/8 etc.) (e.g., Buol et al., 1973). The letter abbreviations refer to the colours of the rainbow, R for red, Y for yellow, YR for yellow red, and the middle of the letter range is at 5. This is a semi-quantitative, subjective (trial and error) method and therefore colour matching was repeated two or more times to minimize ambiguity in colour matching (e.g., Post et al., 1993; Islam et al., 2004). Precise soil colour measurement that is independent of the observer's vision may be obtained from spectroscopic reflectance measurements (e.g., Islam et al., 2004), but a spectrophotometer was not available to us at the time. Results were tabulated and presented as histograms (Figure 3).

\subsection{Magnetic Susceptibility Measurements}

Magnetic susceptibility, the ratio of induced magnetization to an applied magnetic field, has been used successfully to describe soil-forming processes and profile development, to identify lithology of soil parent materials, to aid in soil taxonomy and to assess heavy metal pollution (see Petrovsky \& Ellwood, 1999; Hanesch \& Scholger, 2002; Schibler et al., 2002; Evans \& Heller, 2003; Hanesch et al., 2007; Jordanova et al., 2008). Moreover, in combination with other magnetic parameters, susceptibility can be useful in characterising magnetic mineralogy and granulometry (Hunt et al., 1995; Peters \& Dekkers, 2003). Further, many authors have interpreted magnetic susceptibility enhancement in topsoil in terms of fire, pedological processes, climate or geochemistry of the iron transformations (e.g., Singer et al., 1996; Dearing et al., 2001a, Geiss et al., 2004a,b; Magiera et al., 2006 and references therein).

The magnetic susceptibility is either expressed per unit volume (volume-specific susceptibility, $\kappa$ ) in either $\operatorname{cgs}$ or SI units (both dimensionless; $\kappa_{\mathrm{SI}}=4 \pi \kappa_{\mathrm{cgs}}$ ) or per unit mass (mass-specific or mass-normalised susceptibility, $\chi$ ). Mass specific susceptibility $(\chi)$ is obtained by dividing the volume susceptibility $(\kappa)$ by the bulk density $(\rho)$ of the sample (i.e. $\chi=\kappa / \rho)$, and has mass-based units (e.g., $\times 10^{-6} \mathrm{~m}^{3} / \mathrm{kg}$ ) (see Mullins, 1977). The volume specific magnetic susceptibility $(\kappa)$ was measured using a Bartington MS2 meter/system with B sensor which has the capability of making measurements at two different frequencies: low frequency $(0.46 \mathrm{kHz}, \chi \mathrm{lf})$ and high frequency $(4.6 \mathrm{kHz}, \chi \mathrm{hf})$. Each sample was measured at least two times and averaged, with an air reading before and after each series for correction of drift. All measurements were conducted at the " 0.1 " high-sensitivity setting. To measure the magnetic susceptibility the instrument creates a magnetic field, detects the magnetization of the sample and then calculates the ratio of these, which is the volume magnetic susceptibility of the specimen (Dearing, 1999). SI units are used here in all the measurements as it is recognized as the international standard. In this study, the mass-specific susceptibility $(\chi)$ was calculated from the volume-specific susceptibility using $\chi=$ $10 \kappa / \mathrm{m}$, where $\mathrm{m}$ is the sample mass in grams (Dearing, 1999). 


\subsection{Frequency Dependent Susceptibility}

Magnetic susceptibility can reflect not only the concentration of ferrimagnetic minerals in soil, but also their grain size and types (Thompson and Oldfield, 1986; Hunt et al., 1995; Grimley et al., 2004; Hu et al., 2007). Measurements made at two frequencies are referred to as frequency dependent susceptibility and in this study the procedure involved measuring volume magnetic susceptibility at $0.46 \mathrm{kHz}(\chi \mathrm{lf})$ and $4.6 \mathrm{kHz}$ ( $\chi \mathrm{hf})$. The (percent) difference between readings at the two frequencies can be used for the detection of very fine (ultra-fine) ferromagnetic minerals in soils (Evans and Heller, 2003). This parameter enables assessment of significance of ultrafine super-paramagnetic magnetite grains (Dearing et al., 1996a). These ultrafine grains are formed as a result of burning, pedogenic processes, or bacterial processes (Maher, 1986; Maher and Taylor, 1988; Dearing et al., 1996a; Maher et al., 2003; Hendrickx et al., 2005). Frequency-dependent susceptibility ( $\chi \mathrm{fd}$ ) can indicate the presence of grains lying at the stable single domain-super-paramagnetic (SSD-SP) boundary, around $0.02 \mu \mathrm{m}$ for isodiametric grains (Mullins, 1977; Dearing et al., 1996a; Worm, 1998; Dearing, 1999; Lu et al., 2008). Relatively high $\chi \mathrm{fd} \%$ indicates the concentration of SP grains in soil, and if it is less than 4\%, MD (multi-domain) and PSD (pseudo single domain) or SSD grains dominate (Dearing et al., 1996a, 1997; Evans and Heller, 2003; $\mathrm{Hu}$ et al., 2007). Further, $\chi \mathrm{fd} \%$ is correlated with the age and or the degree of soil weathering (Singer et al., 1996; van Dam et al., 2005), and can also be used to estimate the viscous remanent magnetization of the samples. The frequency dependent susceptibility was calculated as 1) absolute: $\chi \mathrm{fd}=(\chi \mathrm{lf}-\chi \mathrm{hf})$ or $\Delta \kappa=(\kappa \mathrm{lf}-\kappa \mathrm{hf})$, and 2) relative: $\chi \mathrm{fd} \%=100 \times[(\chi \mathrm{lf}-\chi \mathrm{hf}) / \chi \mathrm{lf}]$, where $\kappa l f$ and $\chi \mathrm{lf}$ are the volume specific and mass-specific susceptibility measured at a frequency of $0.46 \mathrm{kHz}$, and $\mathrm{khf}$ and $\chi \mathrm{hf}$ are the magnetic susceptibilities measured at $4.6 \mathrm{kHz}$.

\section{Results}

\subsection{Soil Colour}

The results for soil colour determination are shown in Figure 3. The histogram shows that most soils have appreciable amounts of iron bearing minerals and some iron hydroxides having 10YR and 7.5 YR hues, with a surprisingly large number from Profile P3 over the sandveld. Soils from Profile P2 (Trip 5) show these colours as expected from the hardveld, mainly underlain by granulite gneisses. An appreciable number of samples have hues $5 \mathrm{YR}$ and $2.5 \mathrm{Y}$ with very few in the yellow $(5 \mathrm{Y})$ category. These hues show that the soils are deficient in iron bearing minerals. In some Brazilian Oxisols, samples from mafic rocks showed a variation in colour from 2.5YR to $7.5 \mathrm{YR}$ as reflected in the decrease in magnetization from more than $1 \mathrm{~J} / \mathrm{T} / \mathrm{kg}$ to less than $0.1 \mathrm{~J} / \mathrm{T} / \mathrm{kg}$ of sample (Allan, 1986). The change was attributed to soil yellowing process, induced by both pedogenic and climatic factors in which hematite converts to goethite.

\subsection{Magnetic Susceptibility}

Magnetic susceptibility in this study refers to measurements carried out at room temperature i.e. $\sim 25^{\circ} \mathrm{C}$. The results are presented as profiles mostly in the order in which the trips were conducted as an attempt to contour the data yielded unsatisfactory results. Mass specific susceptibilities (MSS) of profiles chosen are presented in Figures 4 to 7 and generally vary between 0 and $40 \mu \mathrm{m}^{3} / \mathrm{kg}$, with an average of about $6 \mu \mathrm{m}^{3} / \mathrm{kg}$. High values occur over the craton and Limpopo belt areas (the hardveld) while the low values are mainly in areas covered by Kalahari sands (the sandveld). For example, values around Palapye/Marapong in figure 4 are significantly higher than around Nata. However, in some profiles in the hardveld, the values are quite irregular (spiky), showing great variations between adjacent points only $5 \mathrm{~km}$ apart (e.g., Figure 5). It is not possible to explain this pattern at this stage (i.e. reasons for this behaviour are not readily apparent). The highest average susceptibilities are seen in Figure 6, part of profile P2 (Figure 2) and corresponding to soils with high iron minerals (high number of samples with colour 7.5YR, Trip 5, Figure 3). These slightly elevated values over the Limpopo belt are also believed to be due to the higher metamorphic grade (granulite facies) than the craton area (greenschist facies).

Magnetic susceptibility is a function of strongly magnetic particle concentration, grain sizes, grain shapes and mineralogy (Mullins, 1977; Maher, 1986; Thompson \& Oldfield, 1986; Hunt et al., 1995; Evans \& Heller, 2003; Peters \& Dekkers, 2003). Strongly magnetic minerals that contribute to soil magnetic susceptibility (MSS) can be categorized as detrital magnetite (lithogenic), neoformed magnetite and maghemite (pedogenic), or spherical industrial particulates from coal combustion (anthropogenic) (Boyko et al., 2004; Grimley et al., 2004). Although generally low in concentration, these ferromagnetic minerals are orders of magnitude more magnetic (more susceptible) than other common iron minerals. Thus the variations in our profiles reflect changes in the lithogenic and pedogenic contributions, detrital magnetite and neoformed magnetite and maghemite respectively (e.g., Grimley et al., 2004). There is possible contribution of fly ash in figure 4 around Palapye from Morupule coal mine and thermal power station (cf Zhai et al., 2006). 


\section{Soil Colour Histogram}

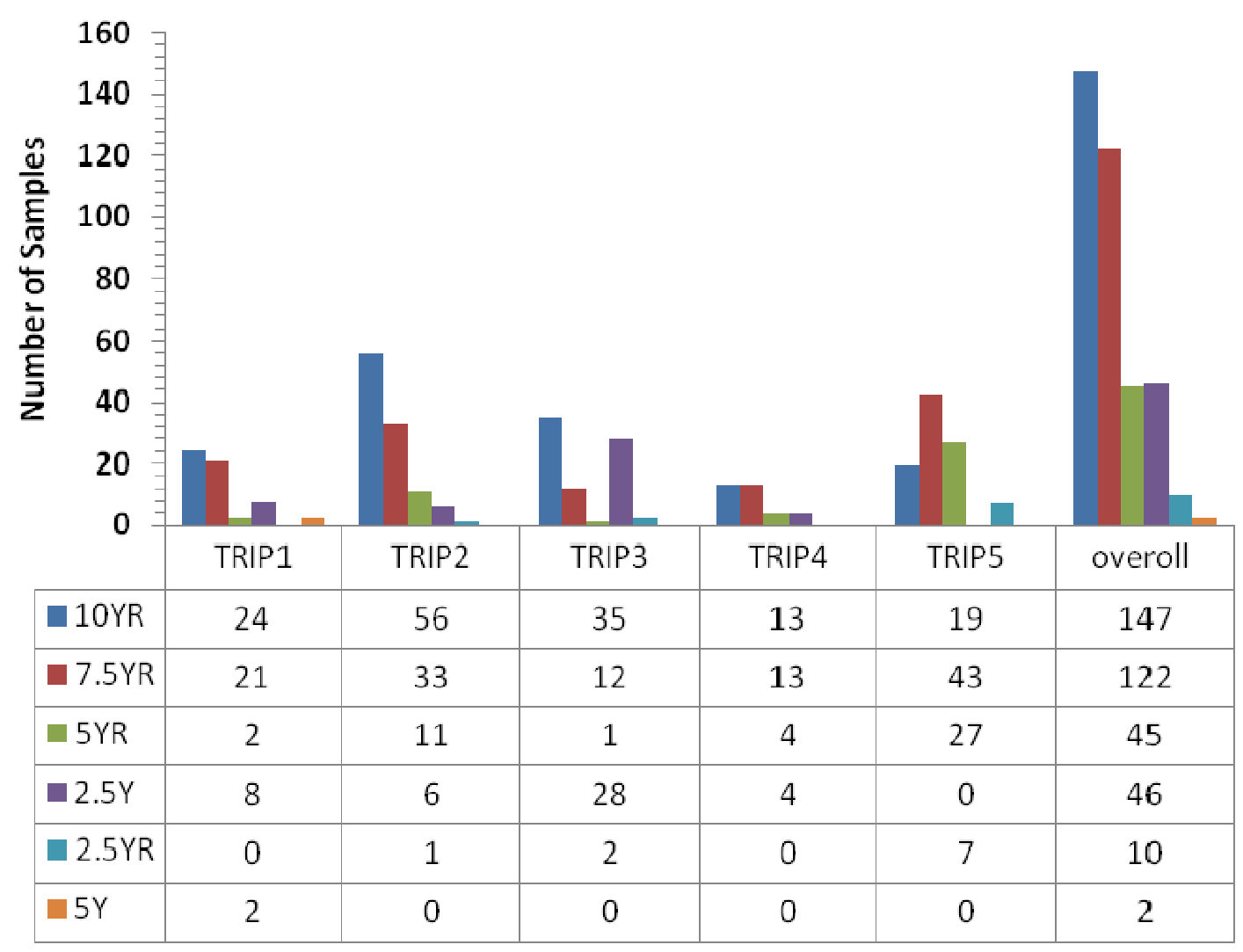

Figure 3. Soil colour histogram for all the (372) samples in the study area

\section{MSS from Palapye to Francistown Via Sebina}

\section{(TRIP 3)}

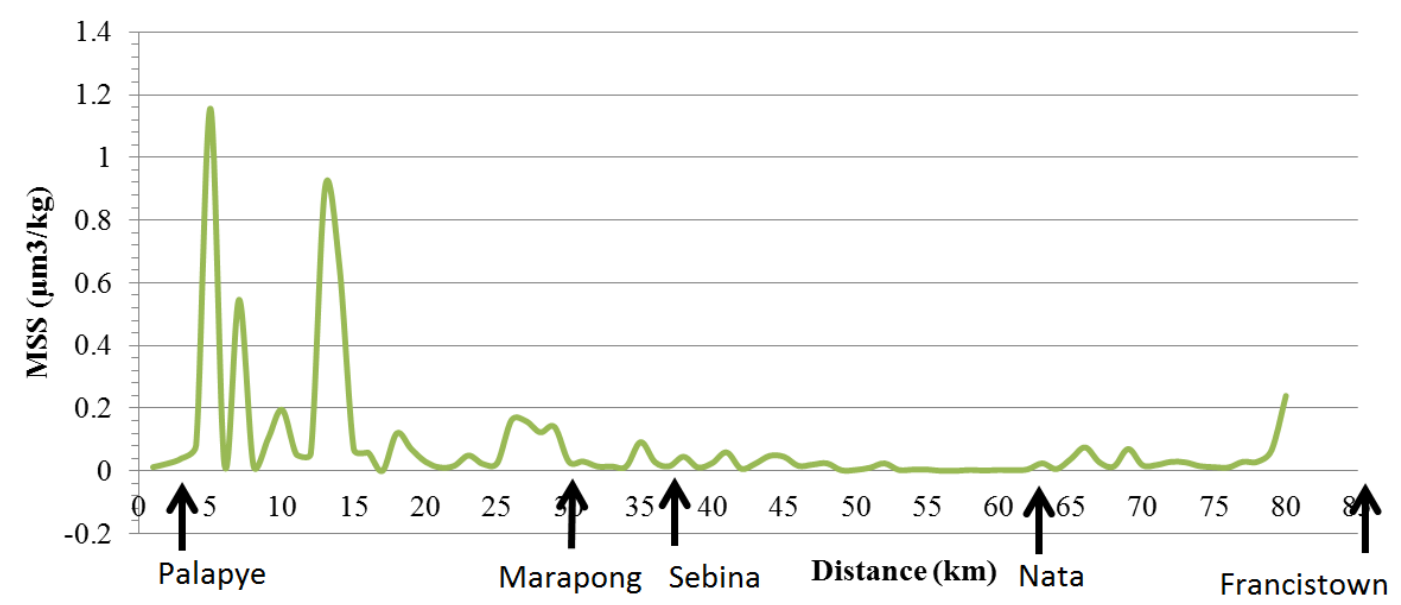

Figure 4. Variation of topsoil Magnetic Susceptibility (MSS) from Palapye-Mokubilo-Sebina- Nata-Francistown (Trip 3; part of purple profile 3 in Figure 2). Limpopo belt (Palapye) on the left through the Kalahari (Nata) in the middle and the Zimbabwe craton (Francistown) on the right 


\section{Mass Specific Susceptibilty}

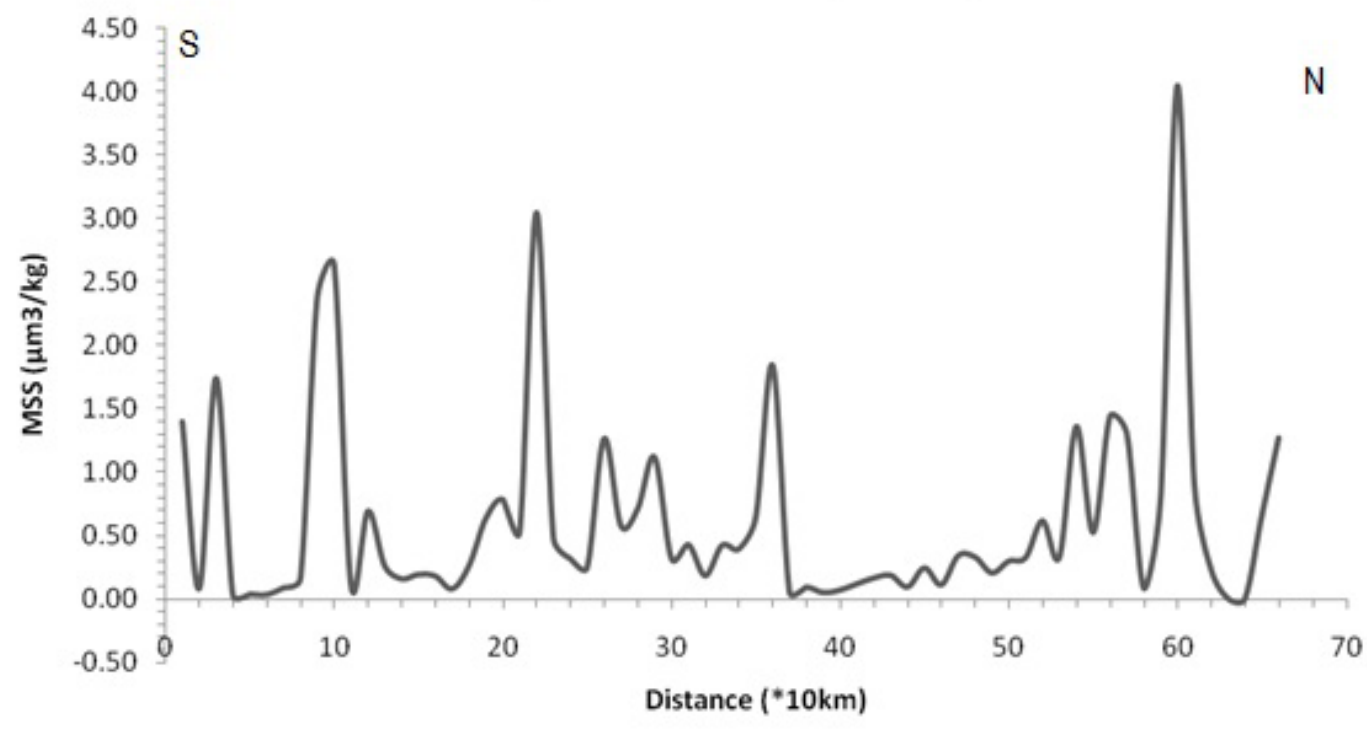

Figure 5. Variation of topsoil Magnetic Susceptibility (MSS) for profile from Ramatlabama (Kaapvaal Craton) in the south to Ramokgwebana (Zimbabwe craton) in the north. [Trip1; Profile P1, Figure 2 (Limpopo belt central zone in the middle)]

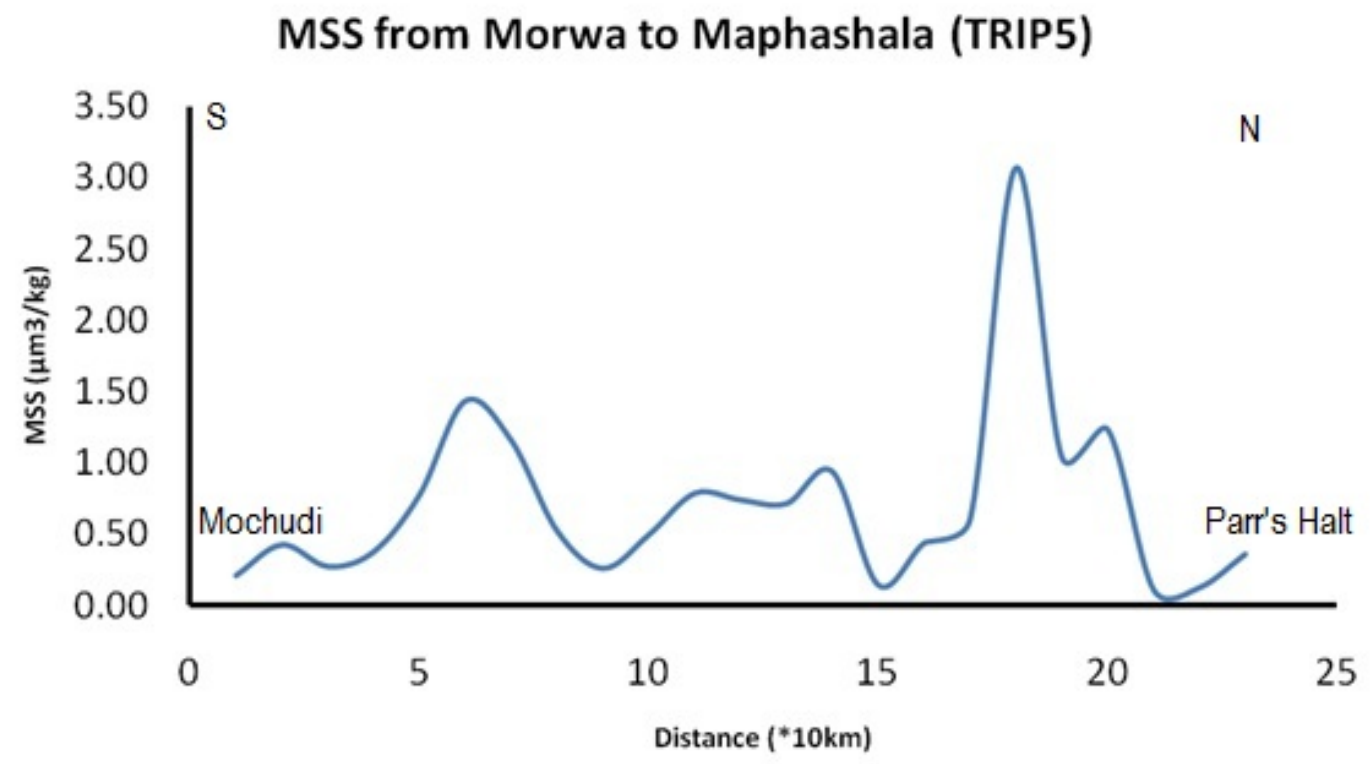

Figure 6. Variation of topsoil Magnetic Susceptibility (MSS) for profile from Pilane/Morwa (Mochudi) in the south to Maphashalala (Parr's Halt) in the north. [Trip5, part of Profile P2 in Figure 2:

quartzo-feldspathic/migmatitic gneiss with Waterberg group conglomerate, coarse sandstone, and shale in between] 


\section{MSS from Bobonong to Selibe Phikwe}

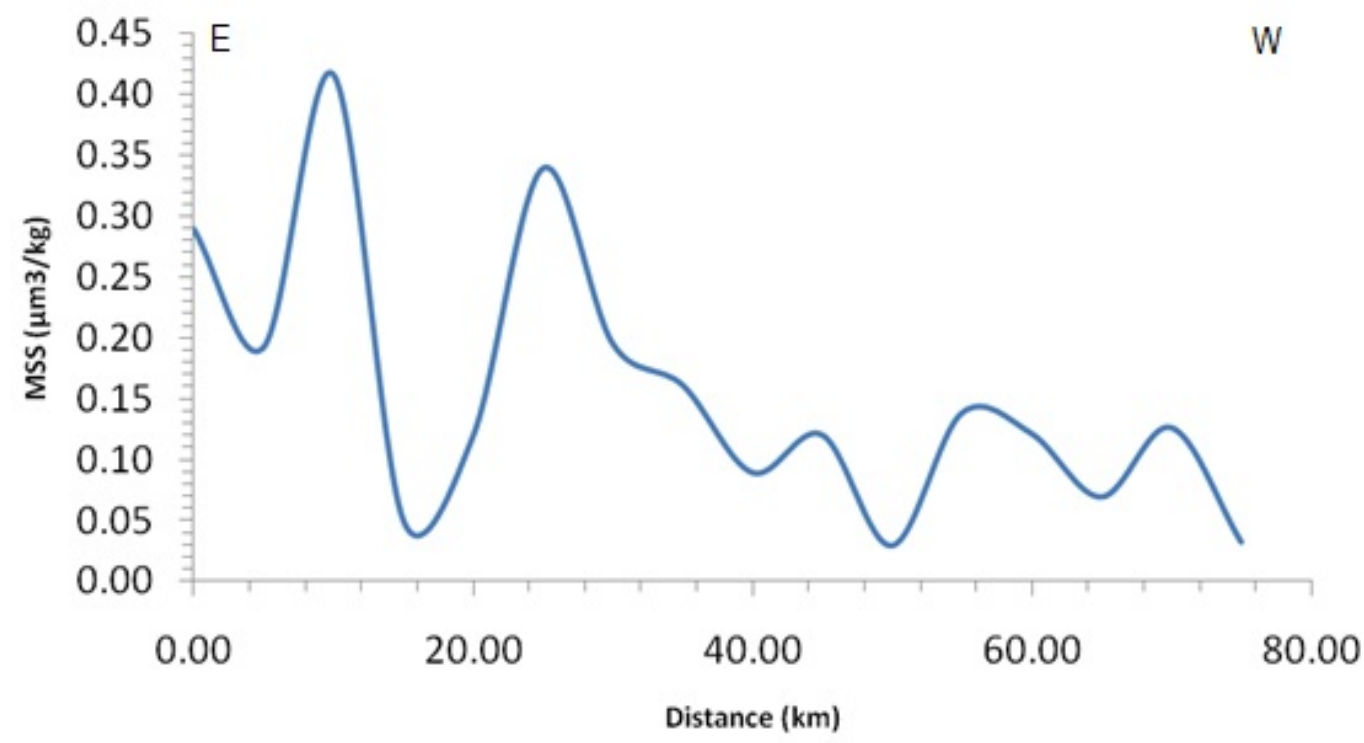

Figure 7. Variation of topsoil Magnetic Susceptibility (MSS) for profile from Bobonong in the east to Selebi-Phikwe in the west. [Trip4; Profile 4 east of (A1) main road, Figure2: Karoo basalts to quartzo-feldspathic gneiss with aeolian sandstone mid-way (covering small area)]

In figure 7, the magnetic behaviour of these soils is, at least in part, caused by the significant concentrations of ferrimagnetic iron oxide minerals that are found in basaltic rocks in the area (e.g., Zhao et al., 2006; Lu et al., 2008; Soubrand-Colin et al., 2009). The susceptibilities vary back and forth between paramagnetic and ferrimagnetic values. This variation may mean that the conditions might have changed from favourable to unfavourable for magnetite formation as a result of weathering processes and hence there is the possibility of magnetite alteration to non-magnetic minerals. Soil parent material strongly determines the amount of iron in the soil system released from weathering that is available for transformation to pedogenic magnetic iron oxides (Dearing et al., 1996b; Cornell \& Schwertmann, 2003). The dominant pedogenic processes that affect MSS are ferrimagnetic mineral neoformation and dissolution, while secondary factors include soil firing and weathering (Singer et al., 1996; Maher et al., 2003; Grimley et al., 2004 and references therein). The latter may correlation with the outbreak of veld fires that are common (annually, during dry winter season when samples were collected) in these areas where there is considerable grass and vegetation.

The above discussion is partly supported by the following further consideration. Samples of rocks and soils without ferrimagnetic minerals, showing purely paramagnetic behaviour, rarely show $\chi$ lf (low frequency mass specific susceptibility) values exceeding $0.1 \mu^{3} \mathrm{~kg}^{-1}$ (Dearing, 1999). Therefore, as a rule-of-thumb, the $\chi$ lf of any sample with a value less than this is probably controlled by the concentration of paramagnetic minerals and for values greater than this by ferrimagnetic minerals. A typical example is shown in figure 8 which is a counterpart of figure 7 . There are exceptions to this rule, especially in some weakly magnetic samples where the susceptibility may be controlled by minute concentrations of ferrimagnetic minerals. The importance of low and high frequency magnetic susceptibility is discussed in more detail in the next section. 


\section{LOW FREQ MAGNETIC SUSCEPTIBILITY BOBONONG TO} SELIBE PHIKWE

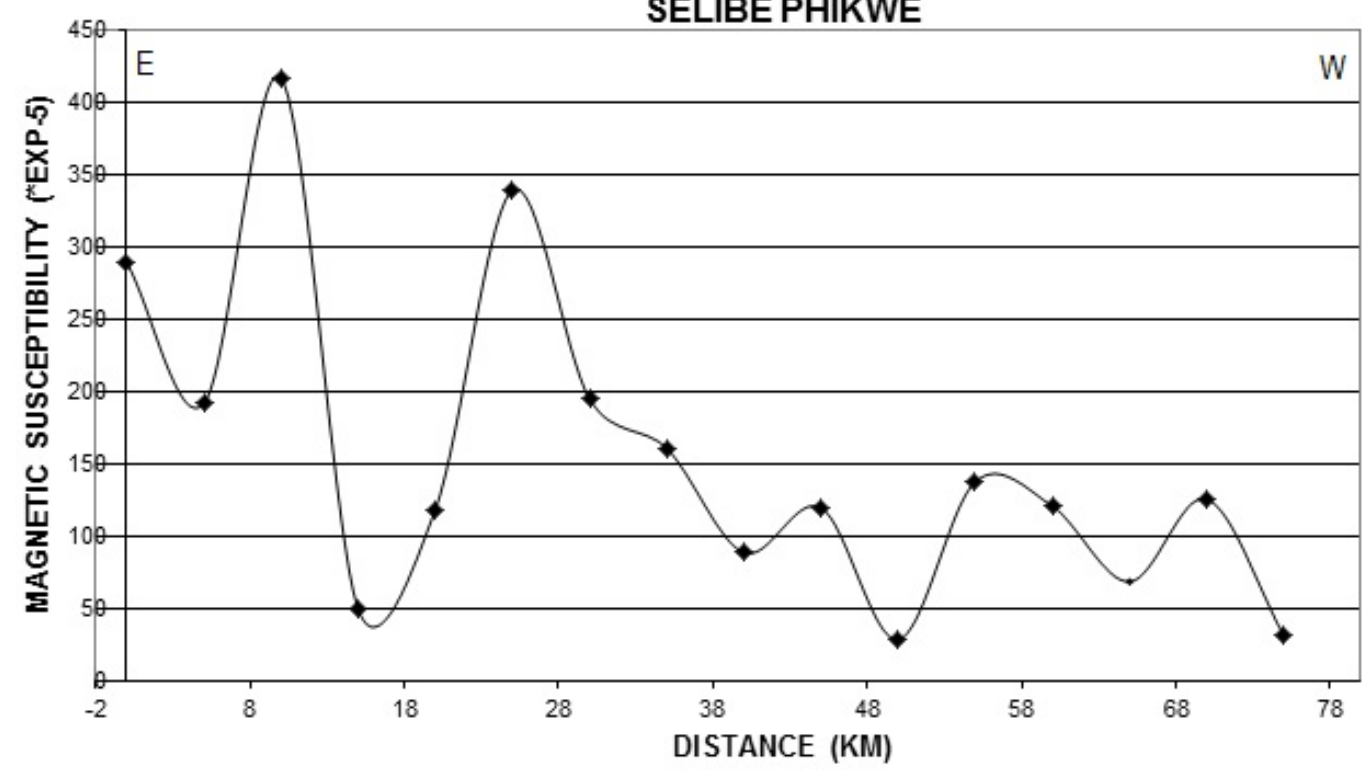

Figure 8. Variation of low frequency magnetic susceptibility from Bobonong in the east to Selibe Phikwe in the west (cf Figure 7)

\subsection{Frequency Dependent Susceptibility}

Frequency dependent susceptibility is used to detect ultra-fine $(<0.03 \mu \mathrm{m})$ super-paramagnetic (SP) minerals occurring as crystals produced by bacteria or by chemical processes in the soil (Dearing et al., 1996a, 1997; Dearing, 1999; Muxworthy, 2001; Maher et al., 2003). In this study, the procedure involved measuring volume magnetic susceptibility at $0.46 \mathrm{kHz}$ ( $\chi \mathrm{lf})$ and $4.6 \mathrm{kHz}(\chi \mathrm{hf})$. Samples where ultra-fine minerals are present will show slightly lower values when measured at higher frequencies whereas samples without the ultra-fine minerals will show identical reading at the two frequencies (Dearing, 1999). This is because at higher frequencies of applied magnetic field, a portion of the small SP grains is unable to follow the field changes and will thus no longer contribute to the susceptibility (Hunt et al., 1995; Worm, 1998; Shi \& Cioppa, 2006).

Values of absolute $(\chi \mathrm{fd})$ and relative $(\chi \mathrm{fd} \%$, normalised to the low-frequency value) frequency-dependent susceptibility range mostly between 0 and $4 \%$ over the Kalahari sands (Figure 9) but from 5 to $12 \%$ in the craton and orogenic belt samples (Figs. 10 to 12). High percentages ( $>6 \%$ ) of frequency-dependent susceptibility reflect the presence of significant numbers of (pedogenic) super-paramagnetic (SP) ferromagnetic grains, with grain diameters <20 nm (e.g., Dearing et al., 1996a; Dearing, 1999; Grimley et al., 2004; Shi \& Cioppa, 2006; Hu et al., 2007). 


\section{Frequency Dependent Magnetic Susceptibilty}

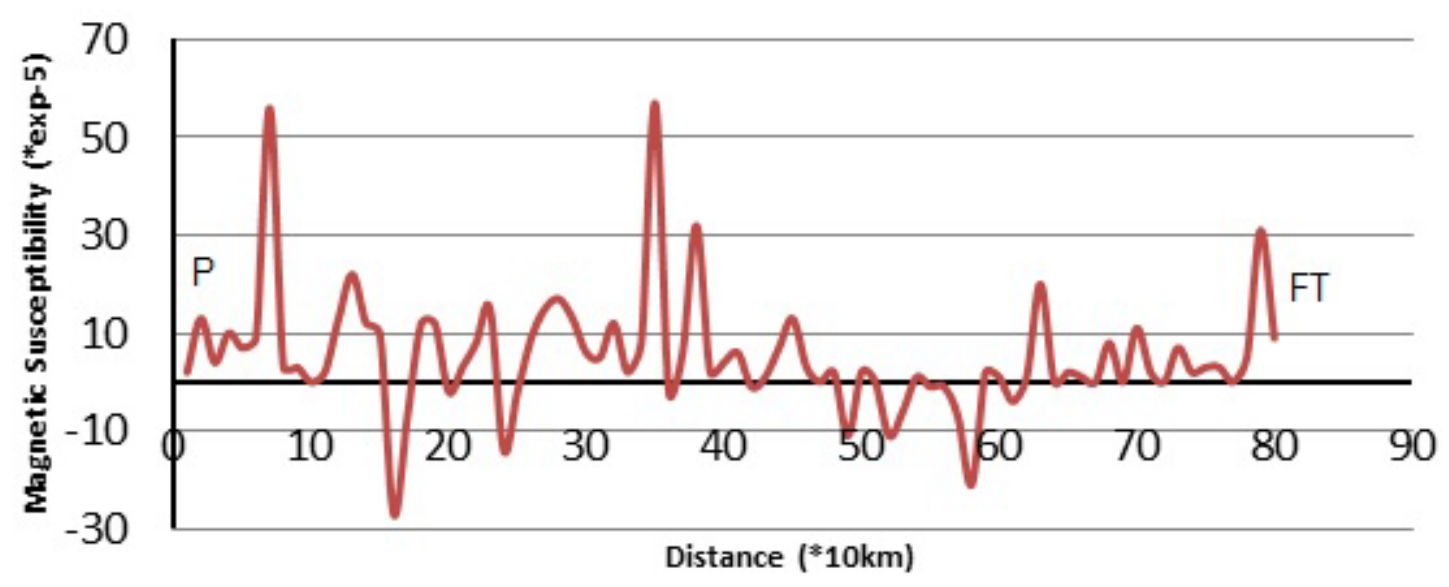

Figure 9. Difference between low frequency and high frequency magnetic susceptibility for Palapye(P)-Marapong- Sebina- Francistown(FT) (Trip 3, cf Figure 4)

\section{Frequency Dependent Magnetic Susceptibility}

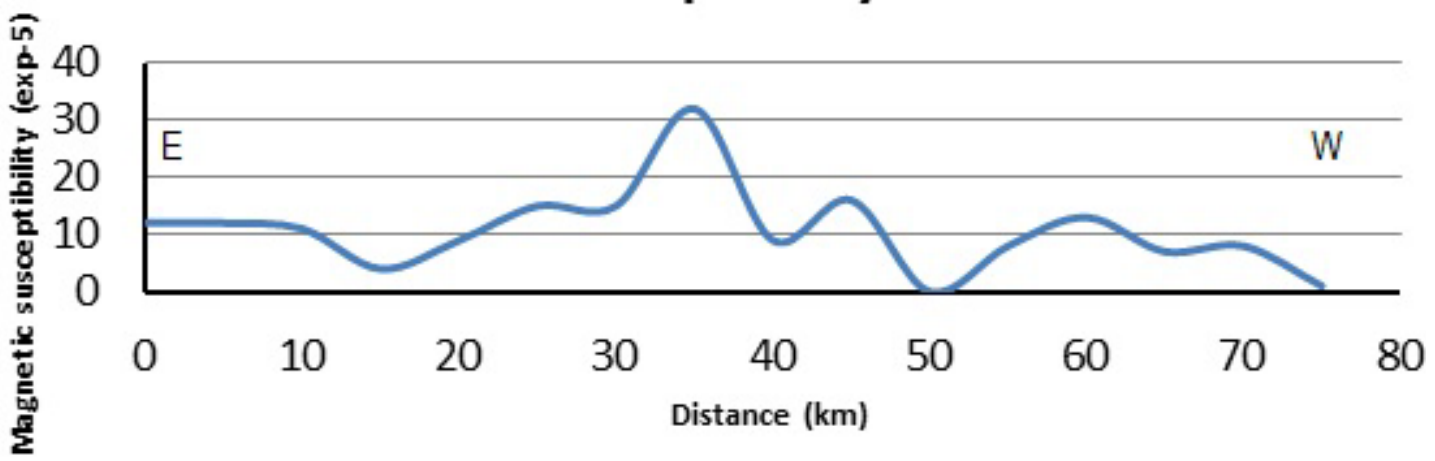

Figure 10. Difference between low frequency and high frequency magnetic susceptibility values from Bobonong in the east to Selibe Phikwe in the west (cf Figures 7 and 8)

Soils with high $\chi \mathrm{fd} \%$ ( $>3 \%$ ) have significant pedogenic magnetite and/or maghemite since both fly ash and detrital magnetite are too coarse to account for such high values (Grimley et al., 2004). This observation implies that the soils are too young and/or the climatological conditions are unfavourable for the neoformation of SP iron oxides (e.g., van Dam et al., 2006). 


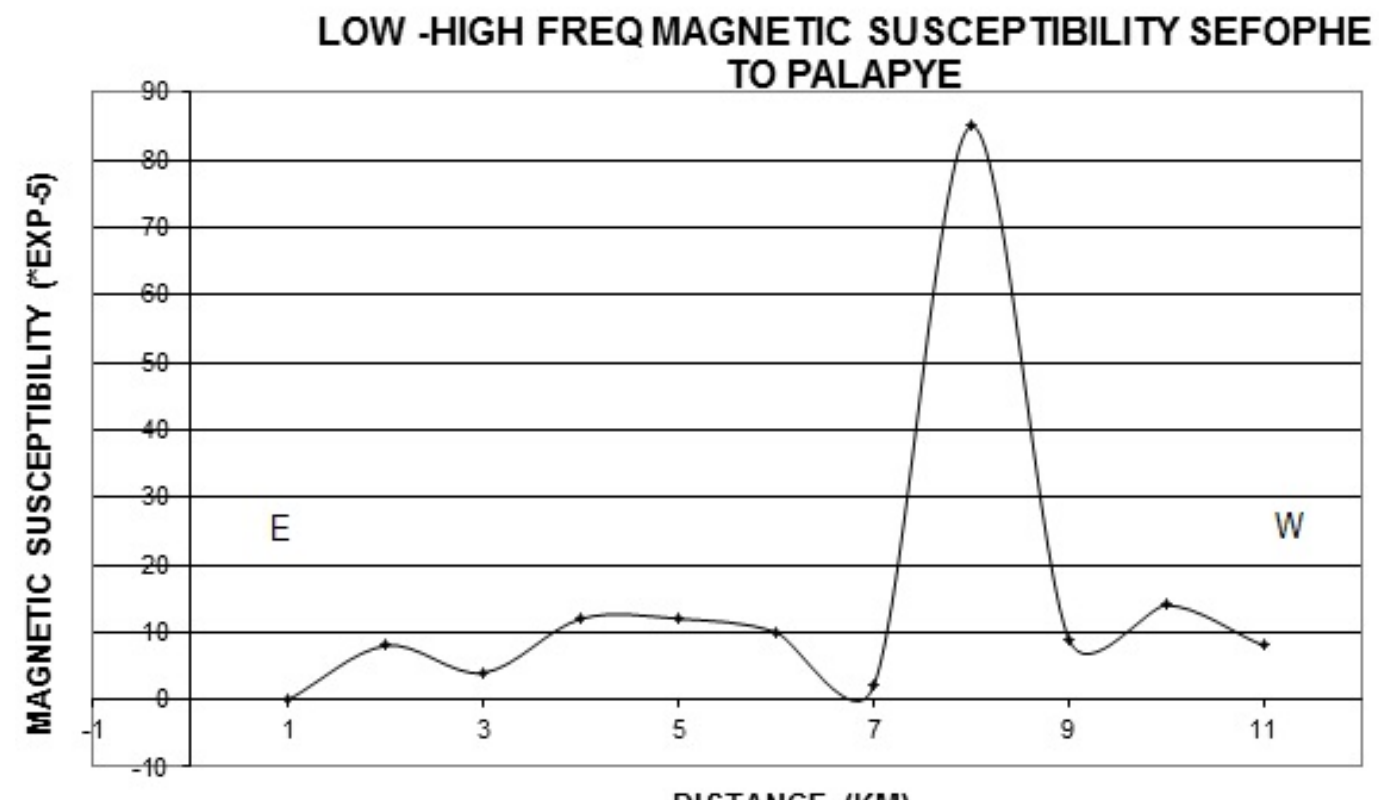

DISTANCE (KM)

Figure 11. Difference between low frequency and high frequency magnetic susceptibility values from Sefhophe in the east to Palapye in the west (Trip4)

\section{Frequency dependant magnetic susceptibility}

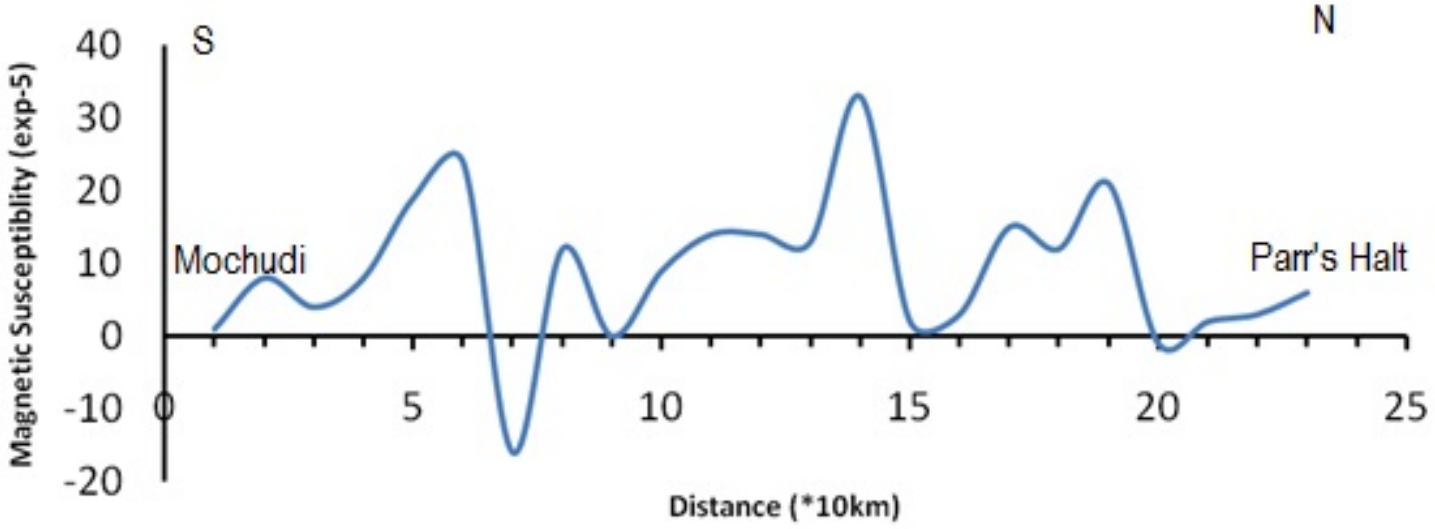

Figure 12. Difference between low frequency and high frequency magnetic susceptibility values from Morwa/Pilane (Mochudi) to Maphashalala (Parr's Halt). [Trip5, cf. Figure 6]

According to Dearing's $\chi \mathrm{fd}$ model (Dearing, 1999), different types of magnetic assemblage can be identified in our soil samples (Figures 9 to 12). The samples with a $\chi \mathrm{fd}<3 \%$ (e.g., Figure 9) are dominated by frequency-independent coarse multidomain (MD) or pseudo-single domain (PSD) grains (e.g., Shi \& Cioppa, 2006). Thus the $\chi \mathrm{fd}$ values $(<3 \%)$ for Lephehe to Shoshong largely in the sandveld indicate a negligible contribution of SP grains to the magnetic properties of the soil, implying that little change has occurred in the relative proportion of SP particles in the period of pedogenesis. The soils belonging to an intermediate group with $\chi \mathrm{fd} \%$ between $3 \%$ and $5 \%$ correspond to a mixture of frequency-dependent and independent grains ( $\mathrm{Lu}$ et al., 2008). A $\chi \mathrm{fd}$ of $5 \%$ or more indicates that the SP particles are present in significant amounts (Maher, 1986, Maher \& Taylor, 1988; Singer et al., 1996), which may reflect pedogenesis. The $\chi \mathrm{fd}$ values of up to $10 \%$ obtained in the profiles of figures 10 and 11 suggest more than $75 \%$ frequency-dependent SP grains in the bulk ferrimagnetic fraction (Dearing, 1999; Lu et al., 2008). 
Therefore, the relative increase of $\chi \mathrm{fd}$ values in profiles of figures 10 and 11 suggest the presence of ultra-fine ferrimagnetic particles. These SP particles are assumed to be authigenic and suggest enhanced pedogenic development (Singer et al., 1996). The results suggest that the soil-forming processes had affected the concentration of particles at the boundary between super-paramagnetic and single domain (SP/SSD) grain size.

Overall, the (percent) frequency dependence of the measured soil samples is generally very low. This indicates a low amount of neo-formed super-paramagnetic (SP) grains, normally associated with soil development. This observation implies that the soils are too young and/or the climatological conditions are unfavorable for the neo-formation of super-paramagnetic iron oxides.

\section{Discussion}

Although soil 'magnetometry' is basically a proxy method, the main advantages are that the methods are fast, inexpensive, mostly non-invasive (non-destructive) and allow investigation of extensive areas within short periods (Petrovsky \& Ellwood, 1999; Yoshida \& Kallali, 2003; Grimley et al., 2004; Shi \& Cioppa, 2006). They are applicable to different geological and environmental settings and give reliable results, partly confirmed by simultaneous geochemical analyses (e.g., Dearing et al., 1996b, 2001a; Fontes et al., 2000; Schibler et al., 2002; Ellwood et al., 2003; Evans \& Heller, 2003; Boyko et al., 2004; Van Dam et al., 2004; Hanesch \& Scholger, 2005; Fialova et al., 2006; Hu et al., 2007; Jordanova et al., 2008).

The soil samples used for this study came from different rocks that span significant geologic time periods, with rather different ages and climatic conditions; and as a result they display variable soil magnetic susceptibility signatures. Magnetic susceptibility of soil samples collected provides evidence that the Kaapvaal Craton, Zimbabwe Craton and Limpopo belt have different magnetic signatures. Lower values of magnetic susceptibility were observed on the Kaapvaal craton ranging from $24 \times 10^{-5}$ to $511 \times 10^{-5}$. The Limpopo Orogenic Belt has values of magnetic susceptibility ranging from $64 \times 10^{-5}$ to $220 \times 10^{-5}$ whereas the Zimbabwe craton has high frequency magnetic susceptibility values ranging $98 \times 10^{-5}$ to $878 \times 10^{-5}$.

The magnetic properties of soils result from the presence of iron oxides in different forms and quantities. Magnetic susceptibility gives an approximate indicator of concentration of the ferromagnetic minerals in the soil ( $\mathrm{Lu}$ et al., 2008). Magnetic minerals present in soils may be either inherited from parent materials (i.e. lithogenic), or be produced by pedogenic (i.e. soil forming) processes, or stem from anthropogenic activities (Cornell \& Schwertmann, 2003; Boyko et al., 2004; Hu et al., 2007). Ferrimagnetic minerals produced in the pedogenic processes are predominantly in the super-paramagnetic (SP) $(<0.02 \mathrm{um})$ to stable single domain (SSD) (0.02-0.04um) grain sizes, while anthropogenic magnetic particles are generally dominated by multiple domain (MD) and SSD sizes (Hu et al., 2007 and references therein). On the other hand, (primary) magnetic materials (mainly magnetite and titanomagnetite) inherited from parent materials tend to be predominantly multidomain (MD) detrital or pseudo-single domain (PSD) grains (0.5-16um), particularly in weakly weathered soils (Grimley et al., 2004; Lu et al., 2008). At the same time, soil parent material strongly determines the amount of iron in the soil system released from weathering that is available for transformation to pedogenic magnetic iron oxides (Dearing et al., 1996b; Cornell \& Schwertmann, 2003).

Soils formed on basaltic parent material in many cases exhibit a very strong magnetic signal. The magnetic behaviour of these soils is, at least in part, caused by the significant concentrations of ferrimagnetic iron oxide minerals that are found in basaltic rocks (e.g., Zhao et al., 2006; Lu et al., 2008; Soubrand-Colin et al., 2009). Paramagnetic and antiferromagnetic iron oxides such as goethite and hematite may be abundant but play a minor role in determining the magnetic character of a soil (Mullins, 1977; Maher, 1986; Grimley et al., 2004; however see Torrent et al., 2006). Ferrimagnetic minerals such as magnetite, maghaemite, and pyrrothite are the most magnetic of the iron oxides (Cornell \& Schwertmann, 2003; Grimley et al., 2004; Hendrickx et al., 2005; Van Dam et al., 2006). Previous work has shown that high values of magnetic susceptibility and frequency dependence of the magnetic susceptibility are especially common in soils in tropical environments developed on basaltic substrate (Hendrickx et al., 2005; Van Dam et al., 2006; Lu et al., 2008).

The magnetic susceptibility profiles (Figs 4 to 7) presented in this study show a great variation of Mass Specific Susceptibility (MSS) along the profile, which indicates the presence of paramagnetic and diamagnetic minerals within the soil samples. Felsic minerals such as quartz and feldspars have low MSS values of magnitude $0.01 \mu \mathrm{m}^{3} / \mathrm{kg}$. Higher mass specific susceptibility values on the profiles are associated with mafic minerals like micas, amphiboles and pyroxenes that are paramagnetic and have mass specific susceptibility in the range 0.1 to $0.5 \mu \mathrm{m}^{3} / \mathrm{kg}$ depending on their magnetite content.

The most common magnetic minerals are the ferrimagnetic minerals like magnetite and titanomagnetite with typical mass specific susceptibilities of around $1000 \mu \mathrm{m}^{3} / \mathrm{kg}$. Other ferrimagnetic minerals are haematite (mass 
specific susceptibility $=1 \mu \mathrm{m}^{3} / \mathrm{kg}$ ) and pyrrhotite (mass specific susceptibility $=100 \mu \mathrm{m}^{3} / \mathrm{kg}$ ). Negative or very low susceptibilities are expected for a soil sample that contains more than $95 \%$ diamagnetic minerals and no ferrimagnetic minerals (Puranen, 1989). Low positive mass specific magnetic susceptibilities (below $0.5 \mu \mathrm{m}^{3} / \mathrm{kg}$ ) characterize a soil that contains more than $5 \%$ paramagnetic minerals without magnetite whereas for soils and rocks containing more than $0.1 \%$ magnetite, the susceptibility values are higher than $1 \mu \mathrm{m}^{3} / \mathrm{kg}$, the value being proportional to the amount of magnetite (Puranen, 1989).

The magnetic susceptibility of samples with volume susceptibilities in the range $0-50 \times 10^{-5}$ is controlled by paramagnetic and diamagnetic minerals. For volume susceptibilities above $50 \times 10^{-5}$, both paramagnetic and ferromagnetic minerals control the susceptibility. The low frequency magnetic susceptibility histograms (not presented in this paper) show that a large number of soil samples have volume susceptibilities ranging between 0 and $50 \times 10^{-5}(\mathrm{SI})$. According to Dearing (1999) soil samples of this range are considered to be weakly magnetic. Their magnetic property is controlled by the presence of paramagnetic minerals like pyrrhotite, ilmenite. The low frequency magnetic susceptibility for trips 2 and 3 are due to the overlaying Kalahari sands and the presence of some sedimentary rocks. Therefore soil from trip 2 and 3 are generally weak in terms of magnetic properties. Most of the soil samples from these trips 2 and 3 have volume susceptibilities controlled by paramagnetic and diamagnetic minerals. Soils from trips 4 and 5 show appreciable amounts of paramagnetic and ferrimagnetic minerals since most of the soil samples from these trips show higher values of magnetic susceptibility. High magnetic susceptibility values are due to soil derived from igneous, ultramafic rocks and other magnetic materials.

The difference between the low frequency and high frequency magnetic susceptibility indicate the presence of ultra-fine super-paramagnetic minerals occurring as crystals produced by bacteria or by chemical processes in the soils (Dearing, 1999). Figure 9 to figure 12 are the susceptibility profiles of the difference between the low and high frequency magnetic susceptibilities. These profiles show varying amounts of ultra-fine particles within the topsoil. In situ formation of (ultra)fine-grained $(<0.1 \mathrm{Am})$ ferrimagnetic minerals through a variety of processes is likely to explain the magnetic enhancement found.

\section{Conclusions}

This work forms part of a multidisciplinary long term project to study various rock and soil environmental characteristics to provide a basic understanding of soil physical properties and processes, and to discuss methods for solving practical problems related to environmental, hydrological, land use and agricultural issues (e.g., Gwosdz et al., 1982; King \& Ranganai, 2001; Moidaki, 2001; Zhai et al., 2003). The study has revealed important soil magnetic signatures from soils derived from different rocks that span significant geologic time periods. More systematic soil magnetic sampling and analysis for smaller areas are now needed, based on the reconnaissance results. We draw the following preliminary conclusions from our data:

1. It was found that soils with hues ranging from 7.5YR to 10YR have appreciable amount of magnetic materials and soils with hues of $2.5 \mathrm{YR}$ are generally nonmagnetic. The combined investigation suggests that the magnetic properties of the darker and yellow-brown coloured samples are controlled mainly by titanomagnetite and maghemite, respectively, but XRD would be needed to check this. For mass specific susceptibility measurements to give undoubted results it is recommended that samples should be in powder form in order to expel the air pockets that are trapped within soil and small rock particles; this will result in unbiased volume and density calculations of soil samples, which are used in the calculation of mass specific susceptibility.

2. The highest, intermediate and lowest MSS were found in soils from the Zimbabwe craton, Kaapvaal craton and the Limpopo orogenic belt, respectively. In relation to the Botswana physiographic units, soils from the hardveld show the highest susceptibilities, followed by those from the sandveld, with the lowest values from the alluvial. Thus the magnetic susceptibility has been able to differentiate soils of varying types and provenance as well as parent material.

3. The magnetic minerals of the rocks selected for this study are of variable particle size but mainly fall within the pseudo-single-domain size range $\left(0.2-14 \_\mathrm{m}\right)$ based on frequency dependent susceptibility. However, further work in the form of XRD, TEM (Transmission Electron Microscopy), and/or MFM (Magnetic Force Microscopy) would be necessary to properly characterize the magnetic particles.

4. This study has demonstrated the potential value of soil magnetic investigations in complementing traditional methods by providing the essential links between magnetic property variations, bedrock geology and different pedogenic regimes.

These results highlight the need for a systematic and continuous evaluation of magnetic properties for 
incorporated into a national GIS data base useful for aeromagnetic (AM) interpretation, industrial minerals and agrominerals (agrogeology), pollution monitoring (particularly urban soils due to high population density); in combination with other geoscience data such as available airborne radiometrics. This also applies to many developing countries in Africa where soil physics, and measurement of soil susceptibility in particular, is generally still at an embryonic stage, with only a few, limited studies reported from Africa (e.g., Dearing et al., 2001b; King \& Ranganai, 2001; Boar \& Harper, 2002; Ishihara et al., 2002; Herries \& Latham, 2003; Yoshida \& Kallali, 2003; Lahlou et al., 2004; Van Dam et al., 2004; Hendrickx et al., 2005).

\section{Acknowledgements}

Many students were involved in the project over the years and their efforts and contributions are greatly appreciated. We thank the reviewers and the associate editor for their constructive comments.

\section{References}

Allan, J. E. M. (1986). The magnetic properties of some Brazilian Oxisols. PhD Thesis, Physics Department, Trinity College Dublin. Reteieved from http://www.tcd.ie/Physics/Research/Mag/jemallan2.html

Alva-Valdivia, L. M., Goguitchaichvilli, A., \& Urrutia-Fucugauchi, J. (2003). Petromagnetic properties in the Naica mining district, Chihuahua, Mexico: Searching for source of mineralization. Earth Planets Space, 55, 19-31.

Boar, R. R., \& Harper, D. M. (2002). Magnetic susceptibilities of lake sediments and soils on the shoreline of Lake Naivasha, Kenya. Hydrobiologia, 488, 81-88.

Boyko, T., Scholger, R., Stanjek, H., \& MAGPROX Team. (2004). Topsoil magnetic susceptibility mapping as a tool for pollution monitoring: repeatability of in situ measurements. Journal of Applied Geophysics, 55, 249-259. http://dx.doi.org/10.1016/j.jappgeo.2004.01.002

Buol, S. W., Hole, F. D., \& McCracken, R. J. (1973). Soil genesis and classification. The Iowa State University Press, Annes, 360pp.

Capital Resources (2013). Botswana Resources Sector Overview 2013/14. Gaborone. 44.

Carney, J. N., Aldiss, D. T, \& Lock, N. P. (1994). The Geology of Botswana, Geological Surveys Department, Bulletin, 37, 113.

Clark, D. A. (1997). Magnetic petrophysics and magnetic petrology; aids to geological interpretation of magnetic surveys. AGSO Journal of Australian Geology and Geophysics, 17(2), 83-103.

Cornell, R. M., \& Schwertmann, U. (2003). The iron oxides: structure, properties, reactions, occurrences and uses. (2nd Ed.). Wiley-VCH, Weinheim.

De Wit, P. V., \& Nachtergaele, F. O. (1990). Explanatory note on the soil map of the Republic of Botswana. AG: BOT/85/011. Field document 30. 48pp

Dearing, J. (1999). Environmental Magnetic Susceptibility Using the Bartington MS2 System. Oxford, England, 104.

Dearing, J. A., Bird, P. M., Dann, R. J. L., \& Benjamin, S. F. (1997). Secondary ferrimagnetic minerals in Welsh soils: a comparison of mineral magnetic detection methods and implications for mineral formation. Geophysical Journal International, 130, 727- 736.

Dearing, J. A., Dann, R. J. L., Hay, K., Lees, J. A., Loveland, P. J., Maher, B. A., \& O'Grady, K. (1996a). Frequency-dependent susceptibility measurements of environmental materials. Geophysical Journal International, 124, 228-240.

Dearing, J. A., Hannam, J. A., Anderson, A. S., \& Wellington, E. M. H. (2001a). Magnetic, geochemical and DNA properties of highly magnetic soils in England. Geophysical Journal International, 144, 183- 196.

Dearing, J. A., Hay, K. L., Baban, S. M. J., Huddleston, A. S., Wellington, E. M. H., \& Loveland, P. J. (1996b). Magnetic susceptibility of soil: an evaluation of conflicting theories using a national data set. Geophysical Journal International, 127, 728-734.

Dearing, J. A., Livingstone, I. P., Bateman, M. D., \& White, K. (2001b). Palaeoclimate records from OIS 8.0-5.4 recorded in loess-palaeosol sequences on the Matmata Plateau, southern Tunisia, based on mineral magnetism and new luminescence dating. Quaternary International, 76-77, 43-56.

Denbow, J., \& Thebe, P. C. (2006). Culture and Customs of Botswana, Greenwood Press, 243pp. 
DLFRS (Dryland Farming Research Scheme), 1985. Ministry of Agriculture, Division of Agricultural research, Phase III, Gaborone, Botswana, Technical Report \#2.

Ellwood, B. B., MacDonald, W. D., Wheeler, C., \& Benoist, S. L. (2003). The K-T boundary in Oman: identified using magnetic susceptibility field measurements with geochemical confirmation. Earth and Planetary Science Letters, 206, 529-540. http://dx.doi.org/10.1016/S0012-821X(02)01124-X

Evans, M. F., \& Heller, F. (2003). Environmental Magnetism- Principles and Applications of Environmagnetics. International Geophysics Series, Vol. 86. Academic Press, Amsterdam. 293pp.

Fialová, H., Maier, G., Petrovský, E., Kapička, A., Boyko, T., \& Scholger, R., MAGPROX Team. (2006). Magnetic properties of soils from sites with different geological and environmental settings. Journal of Applied Geophysics, 59, 273-83. http://dx.doi.org/10.1016/j.jappgeo.2005.10.006

Fontes, M. P. F., de Oliveira, T. S., da Costa, L. M., \& Campos, A. A. G. (2000). Magnetic separation and evaluation of magnetization of Brazilian soils from different parent materials. Geoderma, 96, 81-99.

Geiss, C. E., Banerjee, S. K., Camill, P., \& Umbanhowar (Jr), C. E. (2004a). Sediment-magnetic signature of land-use and drought as recorded in lake sediment from south-central Minnesota, USA. Quaternary Research, 62, 117-125. http://dx.doi.org/10.1016/j.yqres.2004.06.009

Geiss, C. E., Zanner, C. W., Banerjee, S. K., \& Joanna, M. (2004b). Signature of magnetic enhancement in a loessic soil in Nebraska, United States of America. Earth and Planetary Science Letters, 228, 355-367. doi:10.1016/j.eps1.2004.10.011

Grant, F. S. (1985). Aeromagnetics, geology and ore environments, I. Magnetite in igneous, sedimentary and metamorphic rocks: an overview. Geoexploration, 23, 303-333.

Grimley, D. A., Arruda, N. K., \& Bramstedt, M. W. (2004). Using magnetic susceptibility to facilitate more rapid, reproducible and precise delineation of hydric soils in the midwestern USA. Catena, 58(2), 183-213. http://dx.doi.org/10.1016/j.catena.2004.03.001

Gunn, P. J., Maidment, D., \& Milligan, P. R. (1997) Interpreting aeromagnetic data in areas of limited outcrop. AGSO Journal of Geology \& Geophysics, 17(2), 175-185.

Gwosdz, W., Lock, N. P., \& Sekwale M. (1982). Brick earth and Clay Resources of Eastern Botswana. Botswana Geological Surveys, Mineral Resource Report \#5: 169pp.

Hanesch, M., \& Scholger, R. (2002). Mapping of heavy metal loadings in soils by means of magnetic susceptibility measurements. Environmental Geology, 42, 857-870.

Hanesch, M., \& Scholger, R. (2005). The influence of soil type on the magnetic susceptibility measured throughout soil profiles. Geophysical Journal International, ‘50-56.

Hanesch, M., Rantitsch, G., Hemetsberger, S., \& Scholger, R. (2007). Lithological and pedological influences on the magnetic susceptibility of soil: Their consideration in magnetic pollution mapping. Science of the Total Environment, 382, 351-363. http://dx.doi.org/10.1016/j.scitotenv.2007.04.007

Hannam, J. A., \& Dearing, J. A. (2008). Mapping soil magnetic properties in Bosnia and Herzegovina for landmine clearance operations. Earth and Planetary Science Letters, 274(3-4), 285-294. http://dx.doi.org/10.1016/j.eps1.2008.05.006

Hendrickx, J. M. H., Van Dam, R. L., Harrison, J. B. J., Borchers, B., Norman, D. I., Dedzoe, C. D., ... Vlek, P. (2005). Magnetic soil properties in Upper East Region of Ghana. The international Society for Optical Engineering, SPIE Detection and remediation technologies for mines and minelike targets X, 5794, 165-176.

Herries, A. I. R., \& Latham, A. G. (2003). Environmental Archaeomagnetism: Evidence for climatic change during the later Stone Age using the magnetic susceptibility of cave sediments from Rose Cottage Cave, South Africa. In P. Mitchell, Haour, A., \& Hobart, J. (Eds.), Researching Africa's Past: New contributions from British Archaeologists (pp 25-35). Oxford University School of Archaeology Monograph 57. Oxford UK.

Hoffmann, V., Knab, M., \& Appel, E. (1999). Magnetic susceptibility mapping of roadside pollution. Journal of Geochemical Exploration, 66, 313-326.

Hu, X. F., Sub, Y., Ye, R., Li, X. Q., \& Zhang, G. L. (2007). Magnetic properties of the urban soils in Shanghai and their environmental implications. Catena, 70, 428-436. http://dx.doi.org/10.1016/j.catena.2006.11.010 
Hunt, C. P., Noskowitz, B. M., \& Banerjee, S. K. (1995). Magnetic properties of rocks and minerals. In: Ahrens, T.J. (Ed.), Rock Physics and Phase Relations: A Handbook of Physical Constants. American Geophysical Union, Washington, DC. pp. 189-204.

Ishihara, S., Robb, L. J., Anhaeusser, C. R., \& Imai, A. (2002). Granitoid Series in Terms of Magnetic Susceptibility: A Case Study from the Barberton Region, South Africa. Gondwana Research, 5(3), 581-589.

Islam, K., McBratney, A. B., \& Singh, B. (2004). Estimation of soil colour from visible reflectance spectra. SuperSoil 2004: 3rd Australian New Zealand Soils Conference, 5 - 9 December 2004, University of Sydney, Australia. Published on CDROM. Retrieved from http://www.regional.org.au/au/asssi/

Jordanova, N., Jordanova, D., \& Tsacheva, T. (2008). Application of magnetometry for delineation of anthropogenic pollution in areas covered by various soil types. Geoderma, 144, 557-571. http://dx.doi.org/10.1016/j.geoderma.2008.01.021

Key, R. M. (1976). The geology of the area around Francistown and Phikwe, Northeast and central district, Botswana. District Memoir Geological Survey of Botswana Bulletin, 3, 121.

Key, R. M., \& Ayres, N. (2000). The 1998 edition of the National Geological Map of Botswana. Journal of African Earth Sciences, 30(3), 427-451.

Kim, W., Doh, S. J., Park, Y. H., \& Yun, S-T. (2007). Two-year magnetic monitoring in conjunction with geochemical and electron microscopic data of roadside dust in Seoul, Korea. Atmospheric Environment, 41, 7627-7641. http://dx.doi.org/10.1016/j.atmosenv.2007.05.050

King, J. G., \& Ranganai, R. T. (2000). Magnetic Measurements as a proxy for car pollution in Gaborone. Botswana Symposium on Harnessing of Science and Technolody for Economic Development, Proceedings BOSHASTED 2000, p137-140. 28 June - 1 July, Gaborone.

King, J. G., \& Ranganai, R. T. (2001). Determination of magnetite grain-size using the Hopkinson effect examples from Botswana rocks. Botswana Journal of Earth Sciences, 5, 35-38.

Lahlou, S., Mrabet, R., \& Ouadia, M. (2004). Soil Physics: a Moroccan perspective. Journal of African Earth Sciences, 39, 441-445.

Lu, S. G., Xue, Q. F., Zhu, L., \& Yu, J. Y. (2008). Mineral magnetic properties of a weathering sequence of soils derived from basalt in Eastern China. Catena, 73, 23-33. http://dx.doi.org/10.1016/j.catena.2007.08.004

Lyons, R., Oldfield, F., \& Williams, E. (2010). Mineral magnetic properties of surface soils and sands across four North African transects and links to climatic gradients. Geochemistry Geophysics Geosystems, 11, Q08023, 22pp. http://dx.doi.org/10.1029/2010GC003183

Magiera, T., Strzyszcz, Z., Kapic`ka, A., Petrovsky', E., \& MAGPROX Team. (2006). Discrimination of lithogenic and anthropogenic influences on topsoil magnetic susceptibility in Central Europe. Geoderma, 130, 299-311. http://dx.doi.org/10.1016/j.geoderma.2005.02.002

Maher, B. A. (1986). Characterization of soils by mineral magnetic measurements. Physics of the Earth and Planetary Interiors, 42, 76- 92.

Maher, B. A., \& Taylor, M. R. (1988). Formation of ultrafine-grained magnetite in soils. Nature, 336, 368- 370.

Maher, B. A., Alekseev, A., \& Alekseeva, T. (2003). Magnetic mineralogy of soils across the Russian steppe: climate dependence of pedogenic magnetite formation. Palaeogeography, Palaeoclimatology, Palaeoecology, 201, 321-341. http://dx.doi.org/10.1016/S0031-0182(03)00618-7

Maier, G., Scholger, R., \& Schon, J. (2006). The influence of soil moisture on magnetic susceptibility $\begin{array}{lllll}\text { measurements. Journal of } & \text { Applied }\end{array}$ http://dx.doi.org/10.1016/j.jappgeo.2005.10.001

McEwen, G. (1979). The proceedings of a seminar on geophysics and exploration of the Kalahari. Geological Survey Department, Botswana, Bulletin, 22, 423.

Moidaki, M. (2001). Magnetic properties and radiometric signatures of rocks and soils of eastern Bostwana. (Unpublished MSc Thesis), Department of Physics, University of Botswana. Gaborone, Botswana, 158.

Mullins, C. E. (1977). Magnetic susceptibility of the soil and its significance in soil science: A review. Journal of Soil Science, 28, 223- 246.

Munsell, C. (1994). Munsell Soil Colour Charts. (Macbeth Division of Kollmorgen Instruments: New Windsor). 
Muxworthy, A. R. (2001). Effect of grain interactions on the frequency dependence of magnetic susceptibility. Geophysical Journal International, 144, 441-447

Nagano, T., \& Nakashima, S. (1989). Study of colours and degree of weathering of granitic rocks by visible diffuse reflectance spectroscopy. Geochemical Journal, 23, 75-83.

Peters, C., \& Dekkers, M. J. (2003). Selected room temperature magnetic parameters as a function of mineralogy, concentration and grain size. Physics and Chemistry of the Earth, 28(16-19), 659-667. http://dx.doi.org/10.1016/S1474-7065(03)00120-7

Petrovský, E., \& Ellwood, B. B. (1999). Magnetic monitoring of air- land- and water-pollution. In Maher, B. A., \& Thompson, R. (Eds.), Quaternary Climates, Environments and Magnetism, Ch. 8 279-322. Cambridge Univ. Press, Cambridge, 390pp. 335pp.

Post, D. F., Levine, S. J., Bryant, R. B., Mays, M. D., Batchily, A. K., Escadafal, R., \& Huete, A. R. (1993). Correlations between field and laboratory measurements of soil colour. In Bigham, J. M., \& Ciolkosz, E. J. (Eds.), Soil Colour (pp. 35-50). (Soil Science Society of America: Madison).

Preetz, H., Altfelder, S., Hennings, V., \& Igel, J. (2009). Classification of soil magnetic susceptibility and prediction of metal detector performance - case study of Angola. Proceedings of SPIE, 7303,7303131-11.

Pule-Meulenberg, F., \& Batisani, N. J. (2003). A review of Botswana soil fertility research: current status and prospects. UNISWA Journal of Agriculture, 12, 60-67.

Puranen, R. (1989). Susceptibilities, iron and magnetite content of Precambrian rocks in Finland. Geological Survey of Finland. Espoo, Finland. 44pp.

Ranganai, R. T., Moidaki, M., King, J. G., \& Ngwisanyi, T. H. (2006). Magnetic and Radiometric Signatures from Eastern Botswana: Geological and Environmental Implications. $21^{\text {st }}$ Colloquium of African Geology CAG21, Maputo, 3-5 July 2006, Extended Abstract Volume, p452-454.

Reeves, C. V. (1989). Aeromagnetic interpretation and rock magnetism. First Break, 7, 275-286.

Retallack, G. J., Sheldon, N. D., Cogoini, M., \& Elmore, R. D. (2003). Magnetic susceptibility of early Paleozoic and Precambrian paleosols. Palaeogeography, Palaeoclimatology, Palaeoecology, 198, 373-380. http://dx.doi.org/10.1016/S0031-0182(03)00479-6

Schibler, L., Boyko, T., Ferdyn, M., Gajda, B., Holl, S., Jordanova, N., Rfsler, W., \& MAGPROX Team (2002). Topsoil magnetic susceptibility mapping: data reproducibility and compatibility, measurement strategy. Studies in Geophysics and Geodesy, 46, 43-57.

Shi, R., \& Cioppa, M. T. (2006). Magnetic survey of topsoils in Windsor-Essex County, Canada. Journal of Applied Geophysics, 60, 201-212. http://dx.doi.org/10.1016/j.jappgeo.2006.03.002

Singer, M. J., Verosub, K. L., Fine, P., \& TenPas, J. (1996). A conceptual model for the enhancement of magnetic susceptibility in soils. Quaternary International, 34/36, 243-248.

Soubrand-Colin, M., Horen, H., \& Courtin-Nomade, A. (2009). Mineralogical and magnetic characterisation of iron titanium oxides in soils developed on two various basaltic rocks under temperate climate. Geoderma, $149,27-32$.

Thompson, R., \& Oldfield, F. (1986). Environmental magnetism (1st ed). Allen \& Unwin, London. 227pp.

Torrent, J., Barrón, V., \& Liu, Q. S. (2006). Magnetic enhancement is linked to and precedes hematite formation in aerobic soil. Geophysical Research Letters, 33, L02401. http://dx.doi.org/10.1029/2005GL024818

Townsend, W. N. (1973). An introduction to the scientific study of soil (5th ed.). London, 220pp.

Van Dam, R. L., Harrison, B. J., Rittel, C. L., Hendrickx, J. M. H., \& Borchers, B. (2006). Magnetic soil properties at two arid to semi-arid sites in the Westen United States. The international Society for Optical Engineering. SPIE, Detection and remediation technologies for mines and minelike targets XI, 6217-26V5,

Van Dam, R. L., Hendrickx, J. M. H., Harrison, J. B. J., \& Borchers, B. (2005). Conceptual model for prediction of magnetic properties in tropical soils. The international Society for Optical Engineering, SPIE Detection and remediation technologies for mines and minelike targets X, 5794, 177-187.

Van Dam, R. L., Hendrickx, J. M. H., Harrison, J. B. J., Borchers, B., ... Simms, J. E. (2004). Spatial variability of magnetic soil properties. The international Society for Optical Engineering. SPIE, Detection and remediation technologies for mines and minelike targets IX, 5415, 665-676. 
Van Straaten, P. (2002). Rocks for Crops: Agrominerals of sub-Saharan Africa. ICRAF, Nairobi, Kenya, 338pp.

Williams, L., Hall, C., \& Walker, S. (1999). Botswana. Mining Journal Supplement (December 1999). Mining Journal Research Services, The Mining Journal Ltd., London. 16pp.

Worm, H. U. (1998). On the superparamagnetic-stable single domain transition for magnetite, and frequency dependence of susceptibility, Geophysical Journal International, 133, 201- 206.

Yoshida, M., \& Kallali, H. (2003). Environmental Magnetic Study of Surface Soil/Sediment in Northern Tunisia- Field Screening for Potentially Toxic Elements Contamination. Proceedings of the 7th International Symposium on Recent Advance in Exploration Geophysics in Kyoto (RAEG2003), Kyoto University, January 2003

Zhai, M., Kampunzu, H. A. B., Modisi, M. P., \& Totolo, O. (2003). Distribution of heavy metals in Gaborone urban soils (Botswana) and its relationship to soil pollution and bedrock composition. Environmental Geology, 45, 171-180.

Zhai, M., Totolo, O., Modisi, M. P., \& Finkelman, R. B. (2006). Heavy metal and arsenic distributions in soils surrounding Palapye, Botswana: An evaluation of environmental impact of coal mining and combustion in a sub-arid region. Chinese Journal of Geochemistry, 25(1), 53-54.

Zhao, X., Riisager, P., Antretter, M., Carlut, J., Lippert, P., Liu, Q., Galbrun, B., Hall, S., Delius, H., \& Kanamatsu, T. (2006). Unraveling the magnetic carriers of igneous cores from the Atlantic, Pacific, and the southern Indian oceans with rock magnetic characterization. Physics of the Earth and Planetary Interiors, 156, 294-328. http://dx.doi.org/10.1016/j.pepi.2005.08.005

\section{Copyrights}

Copyright for this article is retained by the author(s), with first publication rights granted to the journal.

This is an open-access article distributed under the terms and conditions of the Creative Commons Attribution license (http://creativecommons.org/licenses/by/3.0/). 